\title{
The Role of Product and Market Characteristics in Determining Cottonseed Prices
}

\author{
Sukant K. Mlsra
}

Jane Bondurant

Department of Agricultural \& Applied Economics, Texas Tech University.

\section{ABSTRACT}

The general objective of this research was to determine how variations in cottonseed supply, demand, and quality factors affect cottonseed prices in Texas. A hedonic approach was used in analyzing the influence of product as well as market charactelistics on coltonseed prices, Results indicate that both the product and mal'ket characteristics jointly determine cottonseed prices, and quality premiuns and discounts play an imporant role in price detemnination. Further, results from this study provide praliminary evidence that the cutrent formula pricing system for coltonseed may be overvaluing the pramiums for oil and ammonia and undervaluing the discounts for moisture, free iatty acids, and foreign matter. [L100] 2000 John Wiley Sons, Inc.

\section{INTRODUCTION}

The cotton plant produces approximately 165 pounds of cottonseed for every 100 pounds of lint produced (Nationai Cottonseed Products Association [NCPA], 1989) and many cotton farmers depend on the income from cottonseed sales to offset all or a portion of ginning costs (Hudson, 1946). The two major buyers of cottonseed from gins are oil mills and livestock producers, particulariy dairy producers. Only a smail fiaction of the cottonseed produced each year is used to plant the next year's crop. The farm value of US cottonseed production in 1996 was over 900 million doliars (USDA, 1998). The NCPA. (1997) reports that cottonseed contributes approximately $15 \%$ of farmers' cotton crop revenue.

An important aspect of the cottonseed pricing structure is the grading system utilized in the cottonseed industry. Under this grading system, a sample is taken from each cottonseed shipment as it arrives at the oil mill. An independent, government-authorized laboratory analyzes the sample using specified procedures and reports the grade to the oil mill. Grades are based on the percentages of oil, ammonia, foreign matter, moisture, and free fatty acids contained in the seed sample. The composite grade (CG) is broken into a quantity index and a quality index. The overall grade of cottonseed is determined by

$$
C G=\frac{Q T * Q L}{100}+R
$$

Agribusiness, Vol. 16, No. 3, 357-366 (2000)

Q 2000 John Wiley \& Sons, Inc. 
where QT is the quantity index, QL is the quality index, and $R$ is a rounding factor thit re. ports the composite grade to the nearest one-tenth unit. The quantity index is calcululad is

$$
\mathrm{QT}=(4 * \mathrm{OIL})+(6 * \mathrm{AMM})+\mathrm{V}
$$

where OIL is the oil percentage, AMM is the ammonia percentage, and V is a variety ad. justment factor. The variety adjustment facior equals 5 for upland cottonseed and -10 (t)i American Pima cotton. The formula for the quality index is

$$
\mathrm{QL}=100-(0.4 * \text { FFA })-(0.1 * \text { FM })-(0.1 * \mathrm{M}) .
$$

where FFA represents one unit for every $0.1 \%$ free fatty acids in excess of $1.8 \%$, FM represents one unit for every $0.1 \%$ foreign matter in excess of $1.0 \%$, and $M$ represents one unit for every $0.1 \%$ moisture in excess of $12.0 \%$.

Many oil mills establish a price for 100-grade cottonseed, with premiums for grades high. er than 100 and discounts for grades lower than 100. The cottonseed pricing formula is

$$
\mathrm{FP}_{\mathrm{CS}}=\mathrm{GP}_{\mathrm{CS}} * \mathrm{CG} / 100
$$

where $\mathrm{FP}_{\mathrm{cs}}$ is the sale price of cottonseed determined from the formula and GP $\mathrm{cs}$ is lhw price of 100-grade cottonseed. Gins play the role of a marketing agent for producers und pay for cottonseed on a margin per ton based on the prices at which they can sell the coltonseed and on prices that competing gins are paying producers for cottonseed (Hudson, 1946). Producers do not receive different prices for different lots of cottonseed based on who buys their seed. Instead, they receive an average price per ton that is determined by the gin after cottonseed is sold.

Under this formula pricing system for cottonseed, since the composite grade is multiplied by a market price for 100-grade cottonseed and a vast number of quality combinations can comprise 100-grade cottonseed, there are no widely accepted base levels of quality characteristics. Given this complexity of the pricing structure and a lack of uniformity in pricing decisions, the market values of individual cottonsed quality characteristics are not known.

Classical economic theory wotld suggest that the interaction between cottonseed supply and demand should determine the market equilibrium price of cottonseed, assuming that cottonseed is a homogenous product and the market is competitive. In reality, as evident from the discussion on the cottonseed pricing structure, cottonseed is a composite packagc of characteristics with price deternined in the market by a complex interaction between the classical supply/demand factors and the value of cottonseed characteristics. The general objective of this study was to determine how supply factors, demand factors, and variations in the five cottonseed quality attributes reported under the current grading system (oil, ammonia, foreign matter, moisture, and free fatty acid levels) affect the price of whole coltonseed. This type of information is important to cottor producers because it can be integrated into financial, production, and marketing decisions to improve profitability.

\section{CONCEPTUAL CONSIDERATION}

The hedonic approach has been used extensively for commodity price analysis (Ethridge \& Davis, 1982; Jordon et al., 1985, Perrin, 1980;) and provides a conceptual basis for artiv- 
ing at the ayerage market price differences due to heterogeneity in coltonseed. Fundamental to hedonic theory in price analysis is the assertion that the demend for a commodity is derived from the demand for the characteristics contained in the comunodity. Cottonseed contains a collection of characteristics, and producers of cottonseed products purchase cottonseed because they value the characteristics inherent to it. Cottonseed characteristics include levels of oil, ammonia, free fatty acids, foreign matter, moisture, etc. When a cottonseed lot is offered for sale, it is graded with respect to the identified characteristics, and the associated grading information is made avallable to potential buyers. The value of cottonseed thus can be conceptualized as the summation of the values of all characteristics contained in the set of characteristics that define or comprise cottoniseed. Characteristic value can be determined by multiplying the amount of the attribute contained in cottonseed by the "implicit" price of a unit of the characteristic. These characteristic prices are not, however, directly observable in the marketplace.

As market equilibrium changes aver time, the values of individual quality attributes fluctuate. The values of quality attributes vary because the supply of and demand for these quality atributes are not constant hrough time. A particular combination of coltonseed quality altributes, Z, can be expressed, borrowing Rosen's(1974) notation, as a function of individual quality attributes as follows:

$$
Z=f\left(Z_{l}\right)
$$

where $Z_{i}$ is the amount of the $i^{i n}(i=1,2, \ldots, n)$ cottonseed attribute. Cottonseed is completely described by numerical values of $Z$, and the existence of product differentiation implies the availability of a wide variety of altemative attribute combinations. The price of cottonseed is a function of $Z_{i}$ for ell quality attributes (Brown, 1993).

In addition to quality factors, non-attribute factors (i.e., classical supply and demand factors), affect the price of coltonseed. There is empirical evidence (Chen \& Ethridge, 1996; Hembree et al., 1986) that martet prices of a product are affected by supply and demand factors that cannot be captured by specific quality attributes. The price of cottonseed can, therefore, be viewed as a function of quality, supply, and demand factors. Cottonseed price is defined in the current study as

$$
P_{C S}=g\left(Z_{i}, Y_{S}, Y_{D}\right)
$$

where $Y_{S}$ represents non-attribute supply factors affecting cottonseed prices and $Y_{D}$ represents non-attribute demand factors affecting cottonseed prices. Therefore, the price of cottonseed is determined conceptually by the levels of individual quality attributes as well as non-attribute supply and demand factors.

\section{METHODS AND PROCEDURES}

The empirical analysis of this study was limited to the Texas cottonseed market. Texas is the leading producer of cottonseed and the farm value of cottonseed production in Texas currently averages over $20 \%$ of the farm value of the total cottonseed production in the US. For estimation purposes, a hedonic price model for cottonseed was conceptualized and specified as

$$
P_{C S}=f\left(P P I, Q, L 2 P_{C S O L}, L 2 P_{C S M}\right. \text { OILAMM, MFFAFM), }
$$


where $\mathrm{P}_{C S}$ is the average monthly Texas cottonseed price in dollars per ton (TASS/Texith Cotton Statistics, various issues), PPI is the monthly producer price index for all farm prod. ucts (US Department of Labor, various issues), $Q$ is the annual Texas cottonseed produltion in tons (TASS/Texas Crop Statistics, various issues), L2P $\mathrm{CsolL}_{\text {is }}$ is the average monti. ly US cottonseed oil price lagged two months in cents per pound (USDA, 1986-1997). L2P ${ }_{\text {CSM }}$ is the average monthly Texas cottonseed meal price lagged 2 months in dollars per ton (Feedsuffs), OILAMM is the average monthly oil percentage for Texas cottonsed times the average monthly ammonia percentage for Texas cottonseed, and MFFAFM is the average monthly moisture percentage for Texas cottonseed times the average monthly free fatty acid percentage for Texas cotonseed times the average monthly foreign matter por. centage for Texas cottonseed (USDA, 1987-1996).

The producer price index for all farm products was included in the regression model in capture the effects of changes in the general price level on cottonseed prices. Becuusc monthly Texas coltonseed production data were not available, the annual cottonseed prnduction observation for a given marketing year was repeated for all observations within that marketing year. Therefore, the cottonseed production variable represented annual shifts in cottonseed supply (it is implicity assumed here that Texas cottonseed price is not consicerably influenced by cottonseed production in other states). The cottonseed oil and cotionseed meal price variables represented cottonseed demands factors, and were lagged ? months because oil mills usually enter into contractual agreements with gins by quoting a price for 100 -grade cotionseed prior to the actual delivery of cottonseed.

It was hypothesized that oil and ammonia percentages are analyzed as a combination in the marketplace as evidenced from the quantity index reported under the current grading system. Similarly, the market analyzes moisture, free fatty acid, and foreign matter percentages in combination in the marketplace and thus a multiplicative intaraction term combining these three quality attributes (MFFAFM) was used as an independent variable.

A comprehensive set of individual and joint misspecification tests was undertaken to identify possible misspecification sources and to guide model specification efforts. Join misspecification tests proposed by McGuirk, Driscoll, and Alwang (1993) were first performed to simuitaneously assess parameter stability, functional form, autocorrelation, and heteroscedasticity. Results of the joint misspecification tests revealed possible nonlinearity in the independent variables and possible violation of the assumption of independence, and failed to reject the null hypothesis of homoscedastic emor terms.

Findings of the joint misspecification tests were further evaluated with the help of conmonly used individual diagnostic tests. The White test (Mirer, 1995) was used to assess the regression model for the presence of heteroscedastic error terms. The White test statistic was 34.00; thus the null hypothesis of homoscedastic error terms was not rejected. Pairwise correlation coefficients and variance inflation factors (VIFs) were used to test for the presence of multicollinearity. The VIFs ranged between 1.1 and 2,1 , indicating that multicollinearity was not a problem. The Durbin-Watson test was used to test for first-order autocorrelation. This test statistic, 119, failed to reject the alternative hypothesis of positive autocorrelation at the $5 \%$ significance level. The maximum likelihood method with one autoregressive lag, AR(1), was used to correct the regression model for positive first-order autocorrelation.

The functional form misspecification issue was further investigated by a residual analysis technique discussed in detail in Brown and Ethridge (1995). This technique involved regressing the error temis of the regression equation against an independent variable and its squared term, then trying altemative functional forms of the model in an attempt to remove 
systematic patterns in error terms where applicable. This process was repeated for each independent variabie in the regression equation. Statistically significant parameter estimates in the error term models identified the most likely source variable of the misspecified functional form. Variable transformations, by trial and error, were employed to adjust the functional form of individual variables. Reciprocal specifications for both the cottonseed oil and cottonseed meal price variables appeared to have resolved the functional form misspecification problem, which was further confirmed by the joint misspecification tests proposed by McGuirk et al. (1993). Therefore, the regression model was ultimately specified as

$$
\begin{gathered}
\mathrm{P}_{\mathrm{CS}}=\beta_{0}+\beta_{1} * \mathrm{PPI}+\beta_{2} * \mathrm{Q}+\beta_{3} * 1 / \mathrm{L} 2 \mathrm{P}_{\mathrm{Csni1}}+\beta_{4} \\
* 1 / \mathrm{L} 2 \mathrm{P}_{\mathrm{CSM}}+\beta_{5} \text { OILAMM }+\beta_{6} * \text { MFFAFM }
\end{gathered}
$$

The estinated marginal implicit prices for oil $\left(\mathrm{SP}_{\mathrm{Cs}} / \delta \mathrm{\delta OL}\right.$ ), ammonia $\left(\delta \mathrm{P}_{\mathrm{CS}} / \delta \mathrm{AMM}\right)$, moisture $\left(\delta \mathrm{P}_{\mathrm{Cs}} / \delta \mathrm{M}\right)$, free fatty acids $\left(\delta \mathrm{P}_{\mathrm{Cs}} / \delta \mathrm{FFA}\right)$, and foreign matter $\left(\delta \mathrm{P}_{\mathrm{Cs}} / \delta \mathrm{FM}\right)$ were calculated and then compared to the corresponding marginal implicit prices under the formula pricing system for cottonseed. To calculate the marginal implicit prices under the formula pricing system, equation (4) was rewritten by first substituting equations (2) and (3) into equation (1), and then substituting equation 1 into equation (4) as

$$
\begin{gathered}
\mathrm{FP}_{\mathrm{CS}}=\mathrm{GP}_{\mathrm{CS}}+[[4 * \mathrm{OIL}+6 * \mathrm{AMM}+\mathrm{V}) *[100-(0.4 * \mathrm{FFA} \\
+0.1 * \mathrm{FM}+0.1 * \mathrm{M})] / 100]+\mathrm{R}] / 100
\end{gathered}
$$

Then, the inplicit prices for characteristics, as determined by the formula pricing system, were obtained by differentiating equation ( 9 ) with respect to each characteristic.

\section{RESULTS}

Descriptive statistics for the variables are presented in Table I. Estimates for the cottonseed price model are summarized in Table 2. All the estimated parameters had the expected signs and all except the coefficient for the OILAMM variable were statistically significant. Approximately, $83 \%$ of the total variation in monthly Texas cottonseed prices over the marketing years of 1987 through 1996 could be explained by variations in the independent variables.

\subsection{Cottonseed Price Model Estimates}

The estimated relationship between the producer price index for all farm products and the price of cottonseed suggested that as the producer price index increased by one unit, cotlonseed prices increased by 1.02 dollars per ton, ceteris paribus. The estimated coefficient for the $Q$ variable was statistically different from zero at the 0.14 significance level and was linear. There existed a negative relationship suggesting that, as cottonseed procuction in a given marketing year increased by one thousand tons, the monthly cottonseed price in that marketing year decreased by 0.009 dollars per ton. This inverse relationship existed becausa given the demand for cottonseed, larger quantities of cottonseed available in the marketplace resulted in a lower market price, i.e, higher annual cottonseed supply depressed cottonseed prices, ceteris paribus.

Cottonseed oil prices exbibited a statistically significant, non-linear relationship with cottonseed prices and suggested that as cottonseed oil prices increased, cottonseed prices in- 
TABLE 1. Definitions and Summary Statistics of the Variables Used in the Model

\begin{tabular}{|c|c|c|c|c|}
\hline Variable Definition & Mean & Standard Deviation & Minimum & Mnximum \\
\hline $\begin{array}{l}P_{C S} \\
\text { Monthly Texas } \\
\text { cottonseed price } \\
\text { in dollars/ton }\end{array}$ & 105.74 & 19.13 & 64.00 & 137.161 \\
\hline $\begin{array}{l}\text { PPI } \\
\text { Monthly producer } \\
\text { price index for all } \\
\text { farm products; } \\
\text { unitless }\end{array}$ & 107.05 & 6.35 & 94.90 & 120.20 \\
\hline $\begin{array}{l}\text { Q } \\
\text { Annual Texas } \\
\text { cottonseed production } \\
\text { in tons }\end{array}$ & 1803.49 & 315.95 & 1189.00 & $2 \mid 47,06$ \\
\hline $\begin{array}{l}\text { Pesoih } \\
\text { Monthy Mississippi } \\
\text { Valley Points } \\
\text { cottonseed oil price } \\
\text { in cents/pound }\end{array}$ & 22.44 & 4.06 & 15.44 & 33.16 \\
\hline $\begin{array}{l}\text { Pesm } \\
\text { Monthiy Texas } \\
\text { cotionseed meal price } \\
\text { in dollars/ton }\end{array}$ & 179.24 & 29.16 & 121.50 & 238.25 \\
\hline $\begin{array}{l}\text { OlLAMM } \\
\text { Monthly Texas } \\
\text { cottonseed oil } \% \\
\text { times ammonia } \%\end{array}$ & 73.45 & 7.14 & 66.79 & 121.00 \\
\hline $\begin{array}{l}\text { MFFAFM } \\
\text { Monthly Texas } \\
\text { cortonseed moisture \% } \\
\text { times fre fatty acid \% } \\
\text { times foreign matter \% }\end{array}$ & 10.74 & 9.83 & 2.70 & 55.68 \\
\hline
\end{tabular}

Number of Observations $=58$

creased at a decreasing rate. Interpreted at the historical mean levels of the variables, the estimated relationship indicated that cottonseed prices changed by about $0.26 \%$ as the price of cottonseed oil changed by $1 \%$. Cottonseed meal prices aiso displayed a non-linear relationship with cottonseed prices. The result indicated that cottonseed prices increased at a decreasing rate in response to an increase in cottonseed meal prices. In percentage terms, cottonseed price changed by about $0.39 \%$ as cottonseed meal prices changed by $1 \%$ from their historical mean levels. Since cottonseed demand is derived from demand for cottonseed products such as cottonseed oil and cottonseed meal, increases (decreases) in cottonseed oil and meal demand increased (decreased) the demand for raw cottonseed and, subsequently, increased (decressed) cottonseed prices,

Results presented above suggest that cottonseed price was more responsive to changes in cottonseed meal prices than to cottonseed oil prices. A possible explanation for this finding may be that oil mills pass on a greater proportion of any change in coltonseed meal prices to ginners/producers in an attempt to discourage direct marketing of whole cottonseed to the livestock industry.

The relationship between cottonseed prices and the oil and ammonia interaction term was linear, but the estirnated coefficient was not significantly different from zero. This suggests 
that cottonseed buyers did not refiect their preference for larger combined levels of oil and ammonia in the prices that they offered for cottonseed. The negative effect associated with MFFAFM suggested that as the size of the interaction between moisture, free fatty acids, and foreign matter increased by one unit, cottonseed prices decreased by 0.39 dollars per ton. As the combination of moisture, free fatty acids, and foreign matter in a cottonseed lot increased, the quality of that lol was negatively impacted, e.g., the storage life of the cottonseed decreased. Cottonseet prices reflected the preference for cottonseed containing lower combined levels of these three quality attributes.

\subsection{Estimated Marginal Impllcit Prices}

The estimated marginal implicit prices for oil, ammonia, moisture, free fatty acids, and foreign matter, in their functional forms, appear in equations (10) through (14).

$$
\begin{aligned}
& \text { Marginal Implicit Price for Oll }=\delta \mathrm{P}_{\mathrm{CS}} / \delta \mathrm{OIL}=0.152 * \mathrm{AMM} \text {. } \\
& \text { Marginal Implicit Price for Ammonia }=\delta \mathrm{P}_{\mathrm{CS}} / \delta \mathrm{AMM}=0.152 * \mathrm{OLL} \text {. } \\
& \text { Marginal Implicit Price for Moisture }=\delta \mathrm{P}_{\mathrm{Cs}} / \delta \mathrm{M}=-0.386 * \mathrm{FFA} * \mathrm{FM} \text {. } \\
& \text { Marginal Implicit Price for Free Fatty Acids }=\delta \mathrm{P}_{\mathrm{Cs}} / \delta \mathrm{FFA} \\
& =-0.386 * \mathrm{M} * \mathrm{FM} \text {. } \\
& \text { Marginal Implicit Price for Foreign Matter }=\delta \mathrm{P}_{\mathrm{Cs}} / \hat{\mathrm{FMM}}=-0.386 * \mathrm{M} * \mathrm{FFA} \text {. }
\end{aligned}
$$

Marginal implicit prices for moisture, free fatty acid, and foreign matter were calculated holding the quality attributes not under consideration at the industry average levels $(8.0 \%$ moisture, $0.4 \%$ free fatty acids, and $2.0 \%$ foreign matter) and are reported in Table 3. Resuits indicate that as moisture percentage increased by one unit (e.g., from $8.0 \%$ to 9.0 percent), cottonseed prices decreased by about $\$ 0.31 /$ ton. A one unit increase in free fatty acid percentage (e.g., from $0.4 \%$ to $1.4 \%$ ) resulted in an approximate $\$ 6.17 /$ ton decrease in cottonseed prices. Finally, cottonseed prices decreased by about $\$ 1.23 /$ ton as foreign matter percentage increased by one unit (e.g., from $2.0 \%$ to $3.0 \%$ ). Since the estimated coefficient for the oil and anmonia interaction term was not significantly different from zero even at the 0.15 significance level, the marginal implicit price estimates for oil and ammonia were considiered equal to zaro (Table 3).

TABLE 2. Cottonseed Price Mode! Estimates from Maximum Likelihood Regression

\begin{tabular}{lrrrc}
\hline $\begin{array}{l}\text { Independent } \\
\text { Variables }\end{array}$ & $\begin{array}{c}\text { Coefficient } \\
\text { Estimates }\end{array}$ & $\begin{array}{c}\text { Standard } \\
\text { Error }\end{array}$ & tratio & $\begin{array}{c}\text { Approximate } \\
\text { Probability }\end{array}$ \\
\hline Intercept & 75.752 & 51.570 & 1.469 & 0.148 \\
PPl & 1.025 & 0.345 & 2.971 & 0.005 \\
$Q$ & -0.009 & 0.006 & -1.489 & 0.143 \\
ILIP & -616.788 & 280.800 & -2.196 & 0.033 \\
I/LIP & -7405.017 & 1977.900 & -3.744 & 0.001 \\
OILAMM & 0.152 & 0.171 & 0.885 & 0.380 \\
MFFAFM & -0.386 & 0.123 & -3.131 & 0.003 \\
$R^{2}$ & 0.834 & & & \\
Number of Observations & 58 & & & \\
\hline
\end{tabular}


TABLE 3. Estimated Marginal Implicit Prices for Cottonseed Quality Attributes, Holding Other Altributes at Their Means

\begin{tabular}{|c|c|c|}
\hline Quality Altribute & $\begin{array}{l}\text { Estimeted Market } \\
\text { Marginal Implicit Price }\end{array}$ & $\begin{array}{l}\text { Formula-Plicing } \\
\text { Marginal Implicit Prite }\end{array}$ \\
\hline & \multicolumn{2}{|c|}{$\$ / 10 n$} \\
\hline $\begin{array}{l}\text { Oil } \\
\text { Ammonia } \\
\text { Mloisture } \\
\text { Free falty acid } \\
\text { Foreign matter }\end{array}$ & $\begin{array}{c}0.00 \\
0.00 \\
-0.309 \\
-6.172 \\
-1.234 \\
\end{array}$ & $\begin{array}{r}3.954 \\
5.930 \\
-0.101 \\
-0.404 \\
-0.101\end{array}$ \\
\hline
\end{tabular}

\subsection{Comparison of Estimated and Formula Pricing System Marginal Implicit Prices}

This section complares the estimared marginal implicit prices for the quality characteristics to marginal implicit prices determined by the formula pricing system. Marginal implici prices as determined by the formula pricing system were calculated holding MP at \$100/ ton, OIL at $18.0 \%, \mathrm{AMM}$ at $4.0 \%, \mathrm{FFA}$ at $0.4 \%$, FM at $2.0 \%, \mathrm{M}$ at $8 \%, \mathrm{~V}$ at 5 , and $\mathrm{R}$ at 0 . where applicable.

The marginal implicit prices of oil and ammonia, determined from the current formuli pricing system, were $\$ 3.95$ and $\$ 5.90 /$ ton, respectively (Table 3). These results difier considerably from the findings of this study. While the estimated model did not indicate any statistically significant price premium for additional units of oil and ammonia, the formula pricing system signaled a substantial price-premium for cottonseed with increased level of oil and ammonia.

The formula marginal implicit price of moisture was about $\$ 0.21 /$ ton lower than the estimated marginal implicit price for moisture. This suggests that while the formula pricing system appears to penalize cotton producers approximately $\$ 0.10 /$ ton of cottonseed, the market actually penalized cotton producers approximately $\$ 0.31 /$ tor of cottonseed for an additional unit of moisture. Similarly the marginal implicit price of free fatty acids was about $-\$ 0.40 /$ ton under the formula pricing system and was about $\$ 5.77 /$ ton lower than the marginal implicit price for free fatty acids estimated from the regression equation (Tabie 3). This further suggests that the market actually penalized coton producers more for an additional unit of free fatty acids than what the formula pricing system appears to signal, Results on the marginal implicit price of foreign matter ajso indicated that the formula pricing system appears to undervalue the penalty than the market ( $\$ 0.10$ versus $\$ 1.23 /$ ton).

\section{CONCLUSIONS}

This study represents a first analytical attempt to understand the role of both product and market characteristics in cottonseed price determination. Results indicate that both the product and market characteristics jointly determine cotonseed prices, and quality premiums and discounts play an important role in price determination. Further, it provides prelimitary evidence that the current formula pricing system for cottonseed may be overvaluing the premiums for oil and ammonia and undervaluing the discounts for moisture, free fatty acids, and foreign matter.

It is not obvious why such a discrepancy existed between the formula pricing system and the resuits of this study. If the formula pricing system is being scrupulously used by buyers 
to price cottonseed, then the empirical analysis should have closely reflected pricing signals revealed by the formula. Closer scrutiny of the current formula pricing system may provide some insight into the discrepancy revenled in this study. An explanation may lie in the methods used by the buyers to calculate the composite grade and the price of cottonseed. First, there are no widely accepted base jevels for the quality attributes and a vast number of quality combinations can comprise 100-grade cottonseed. Further, the buying price for coltonseed is deternined by muttiplying the composite grade by a price for 100 -grade cotonseed; however, there are no established means by which producers/ginners can determine the market price for 100 -grade cottonseed. Thus, a quoted price for 100 -grade cotconseed that is lower than what is dictated by market characteristics can easily distort premium and discount signals in a manner that is consistent with the findings of this study. In this case, the current formula pricing system may be sending cottonseed market participants inaccurate signals concerning the values of the different quality attributes contained in cotlonsecd.

Due to the unavailability of price and quality data for individual cottonseed lot sales, this study ralied on aggregate data. As was pointed out by an anonymous reviewer, the parameter estimates of the hedonic model are likely biased due to the aggregation of the quality data. The magnitude of the potential bias in the estimated parameters of this study is not known because the variability of the cottonseed attributes across lots is currently unavailable. If relatively large bias is present, then the data aggregation problen could have caused the observed discrepancy between the formula pricing system and the restits of this study. It is, therefore, important that results of this study are further validated using price and quality data for individual cottonseed lot sales.

\section{ACKNOWLEDGMENTS}

The authors acknowledge the comments of Don Ethridge, Phil Jonnson, Jeff Johnson, and Octavio Ramirez on this report, and the funding provided by Texas Tech University Cotton Economics Research Institute. Texas Tech University, College of Agricultural Sciences and Natural Resources Publication Number T-1-501.

\section{REFERENCES}

Brown, J.E. (1993). The optimal hedonic model structure for daily cotton matket price reporting. Unpublished master's thesis, Texas Tech University, Lubbock, TX.

Brown, J.E., \& Elbridge, D.E. (1995). Functional form model specification: An application to hedonic pricing. Agriculture and Resource Economics Review, 24, 166-173.

Chandler, P. (1992). Various factors affect market value of whole cottonseed. Feedstufis (pp. 17-18).

Chen, C., E Elhridge, D.E. Textile market yaluation of colton quality altributes. Presented at NCR134 Conference: Applied Commodity Price Analysis, Forecasting, and Market Risk Management, Chicago, IL, April 22-23, 1996 ,

Ethridge, D.E., \& Davis, B. (1982). Hedonic price estimation for commoditics: An applicatión to co:lon. Western Journai of Agrieultural Economics, 7, 293-300.

Feedstuffs, (1987-1996). Vols. 59-68. Minnetonka, MN: The Millcr Publishing Company.

Hembree, J.F., Eliridge, D.E., \& Neeper, J. T. (1986). Market values of tiber properties at southeasten mill poinis. Textile Research Journal, 56, 140-144.

Hudson, J.F, (1946). Marketing of cottonseed in Louisiana. Loujsjana State University and Agricullural and Mechanical College Agriculural Experiment Stations, Louisiana Bulletin No. 400, Balon Rouge, LA.

Jordon, J.L., Shewfell, R.L., Prussia, S.E., \& Hulst, H.C. (1985). Estimating implicit market prices of quality characteristics of tomatoes. Southern Journal of Agricultural Economics, 17, 139-45. 
McGuirk, A.M., Driscoll, P., \& Alwang, J. (1993). Misspecification testing: A comprehensive approach. American Journal of Agricultural Economics, 75, 1044-1055.

Mirer, T.W. (1995). Economic statistics and econometrics (3rd ed.), Englewood Cliffs, New Jersę: Prentice-Hall.

National Cottonseed Products Assnciation. (1989). Cotlonseed and its products (9th eỏ.), Memphis. TN.

National Cottonseed Products Association. (1997). Cottonseed; The inside story. Memphis, TN.

Perrin, R.K. (1980). The impect of component pricing of soybeans and milk. Amelican Journal uf Agricultural Economics, 62, 445-55.

Rosen, S. (1974). Hedonic prices and implicit markets: Product differentiation in pure competition. Journal of Political Economics, 82, 34-55.

Texas Agricultural Statistics Service. (1986-1989;1994-1996). Texas Agricultural Statistics, Austin. TX: US Department of Agriculture and Texas Departınent of Agriculture.

Texas Agricuttural Statistics Service, (1972-1979). Texas cotton statistics, Austin, TX: US Department of Agriculture and Texas Department of Agriculture,

Texas Agricultural Statistics Service. (1990-1993). Texas crop statistics, Austin, TX: US Department of Agriculture and Texas Department of Agriculture.

US Department of Agriculture. (1987-1996). Cottonseed quality: Crop of 19XX. Memphis, TN: Agricultural Marketing Service.

US Department of Agriculture, (1986-1997). Oil crops situation and outlook yearbook, Washingtom. DC: Economic Research Service.

US Department of Labor. (1991-1996). Producer price indexes: Data for 19XX. Washington, DC: Bureats of Labor Statistics.

Sukant K. Misra is an Associate Professor in the Department of A gricultural a Applied Economics; Tevas Tech Universily, Lubbock, TX.

Jane Bondurant is a former Research Assistant in the Deperiment of Agriculturat \& Applied Eco. nomics, Texas Tech Universiry, Lubbock. TX. 